\title{
Genetic and morphometric differences between yellowtail snapper (Ocyurus chrysurus, Lutjanidae) populations of the tropical West Atlantic
}

\author{
Anderson V. Vasconcellos ${ }^{1}$, Paulo Vianna ${ }^{2}$, Paulo C. Paiva ${ }^{3}$, Renata Schama ${ }^{1}$ and Antonio Solé-Cava ${ }^{1}$ \\ ${ }^{1}$ Universidade Federal do Rio de Janeiro, Instituto de Biologia, Departamento de Genética, \\ Laboratório de Biodiversidade Molecular, Rio de Janeiro, RJ, Brazil. \\ ${ }^{2}$ Projeto TAMAR, Praia do Forte, Rio Vermelho, Salvador, BA, Brazil. \\ ${ }^{3}$ Universidade Federal do Rio de Janeiro, Instituto de Biologia, Departamento de Zoologia, \\ Laboratório de Polychaeta, Rio de Janeiro, RJ, Brazil.
}

\begin{abstract}
Populations of Ocyurus chrysurus were compared genetically and morphometrically along the West Atlantic coast to test the null hypothesis of population homogeneity in the area. Brazilian populations were found to be differentiated in shape (canonical variates analysis; $F_{[48.515]}=10.84, p<0.0001$ ). Analyses of mitochondrial DNA sequences (663 bp of the control region) did not show any differences between Brazilian populations but could detect differences between Brazilian and Caribbean (Belize) populations. The samples from Pernambuco differed significantly from the other Brazilian populations in allozyme frequencies (11 loci; $\left.F_{S T}=0.167 ; p<0.05\right)$, but this may have resulted from the small number of samples analysed for that population. Sequence variation of Belize samples departed from neutral expectations (Fu's FS = -8.88; $\mathrm{p}<0.001$ ). A mismatch distribution analysis points to an ancient population expansion in that area. We conclude that the genetic data do not allow the rejection of the null hypothesis of panmixia for Brazilian yellowtail snapper populations which should be treated as a single genetic stock, with a latitudinal gradient on their morphology which probably results from phenotypic plasticity. On the other hand, there is a severe restriction to gene flow between $O$. chrysurus populations from the Caribbean and from the southwestern Atlantic.
\end{abstract}

Key words: mtDNA, allozymes, morphometry, fisheries, phylogeography.

Received: November 27, 2006; Accepted: October 7, 2007.

\section{Introduction}

The yellowtail snapper Ocyurus chrysurus (Bloch, 1791) is a Lutjanid reef fish found on the east coast of the Americas from New England (USA) to southeastern Brazil (Menezes and Figueiredo, 1980; Allen, 1985). It is dioecious and its spawning times vary between geographic regions (Thompson and Munro, 1983; Claro, 1983; Grimes, 1987). O. chrysurus has opportunist and generalist alimentary habits and, hence, it is an important predator in some reef zones (Fallows, 1984; Parrish, 1987). They are longlived (up to 17 years Allman et al., 2005) and their larvae are pelagic (Riley et al., 1995).

Yellowtail snappers are important fisheries resource where they occur. The production of the species in Northeast Brazil is high (Costa et al., 2003) by 2001 averaging 1683 tons.year $^{-1}$ (Resende et al., 2003). In Southeast Brazil

Send correspondence to Antonio M. Solé-Cava. Laboratório de Biodiversidade Molecular, Departamento de Genética, Instituto de Biologia, Universidade Federal do Rio de Janeiro, Avenida Pau Brasil 211, Ilha do Fundão, 21941-590 Rio de Janeiro, RJ, Brazil. E-mail: sole@ biologia.ufrj.br. yellowtail snappers accounted for $16 \%$ of the total fish biomass captured between 1986-1989 (Paiva and AndradeTubino, 1998). The formation of spawning aggregations in this species (Claro, 1983) makes it particularly vulnerable to overfishing (Costa et al., 2003), so that it is important that the stock structure of this species be known in order to better preserve it. This is also important because of the reported post-recruitment site fidelity of this species (Watson et al., 2002) which might lead to large stock differentiation and fragility.

In recent years there has been a worldwide decrease in fishing stocks (Garcia and Grainger, 2005; Pauly et al., 2005): the overexploited, fully exploited and exhausted fisheries that were $69 \%$ in 1995 increased to $75 \%$ in 2002 and only $1 \%$ of the stocks are in a state of recuperation (FAO, 2002; Ormerod, 2003). Similar problems are faced by the Brazilian fisheries stocks (Vasconcellos and Gasalla, 2001). For this reason efficient management policies based on unambiguous scientific data are necessary both to protect the fishing stocks and to maximize their exploitation without compromising their integrity. The correct stock as- 
sessment and identification of the species is fundamental to establish the maximum sustainable effort of a given marine resource (Ryman and Utter, 1987; Ryman, 1991). Many stock concepts can be found in the literature (Booke, 1981; Ovenden, 1990; Smith et al., 1990; Carvalho and Hauser, 1995), but one of the most accepted and used is that "a stock is an intraspecific group of randomly mating individuals with temporal and spatial integrity" (Ihssen et al., 1981) which covers most of the definitions given by other authors.

The identification of fish stocks can be made efficiently by the use of highly polymorphic molecular markers (Blaber et al., 2005; Caddy and Seijo, 2005; Carmen and Ablan, 2006). In this study nuclear (allozymes) and mitochondrial (control region sequences) markers are used for the first time to analyse the stock structure of populations of O. chrysurus along $2380 \mathrm{~km}$ of Brazilian coast. A significant latitudinal gradient was observed for geometric morphometric data. The lack of observable heterogeneity in allozymes or in the highly variable mitochondrial DNA sequences indicates that this variation results from phenotypic plasticity. Additionally, samples from the Caribbean differed genetically from the Brazilian ones indicating restriction in gene flow between the two areas for this fish species.

\section{Material and Methods}

\section{Sampling}

Specimens of Ocyurus chrysurus were collected between August and October 2001 by fishing vessels from four locations along the Brazilian coast (Table 1; Figure 1). Samples of muscle and liver tissues from each fish were transported frozen to the laboratory where they were stored in liquid nitrogen until analyses. Muscle samples from $O$. chrysurus were also collected in Belize $\left(17^{\circ} 29^{\prime} 34^{\prime \prime} \mathrm{N}\right.$, $88^{\circ} 06^{\prime} 00^{\prime \prime} \mathrm{W} ; \mathrm{N}=20$ ) and transported in $90 \%$ ethanol to the laboratory where they were used in DNA sequencing.

\section{Morphometric analyses}

Morphometric variation among populations was assessed through geometric methods (Zelditch et al., 2004). For this purpose all 192 individuals collected at the four localities were measured. Measurements were taken with a Vernier manual calliper ( $0.05 \mathrm{~mm}$ of precision) between 10 homologous landmarks using a truss network protocol (Strauss and Bookstein, 1982) which provided 21 interlandmark distances (Figure 2).
To retain the relative geometry of landmarks, interlandmark distances were converted to Cartesian landmark coordinates for each specimen using the import truss feature of the Morpheus program (Slice, 1998). Landmark coordinates were then adjusted by the generalized least squares Proscrustes superimposition (GLS) method (Rohlf and Slice, 1990), centering all specimens, and scaling them to an equal centroid size. The GLS-adjusted landmark coor-

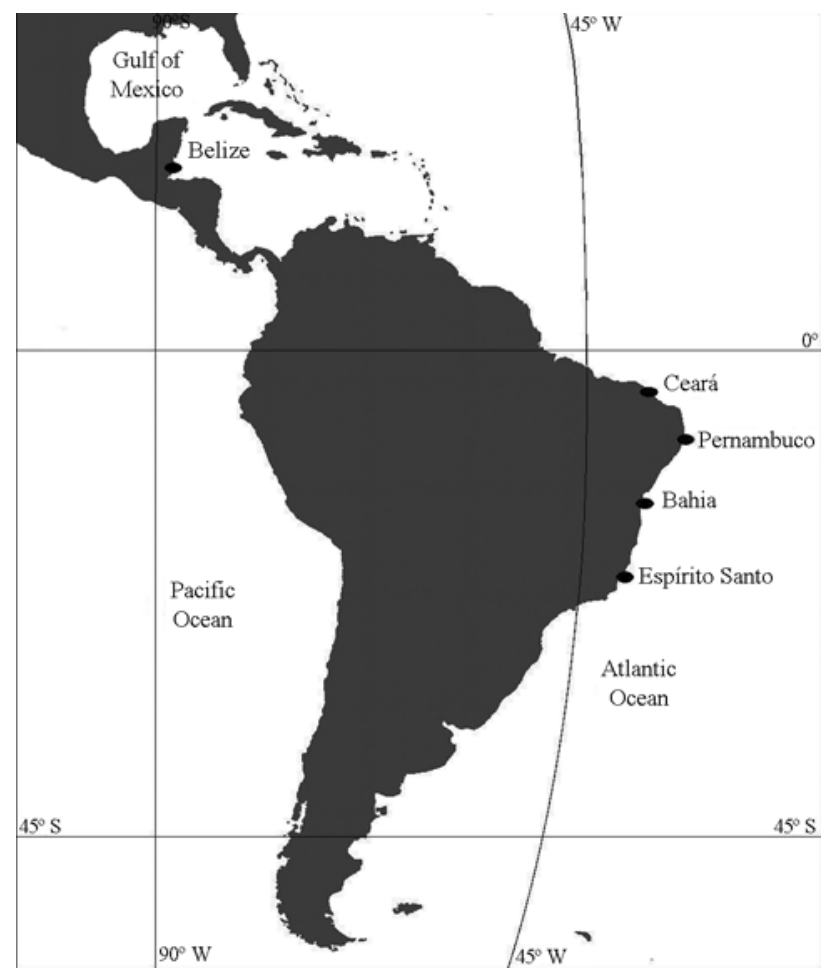

Figure 1 - Collection localities of Ocyurus chrysurus.

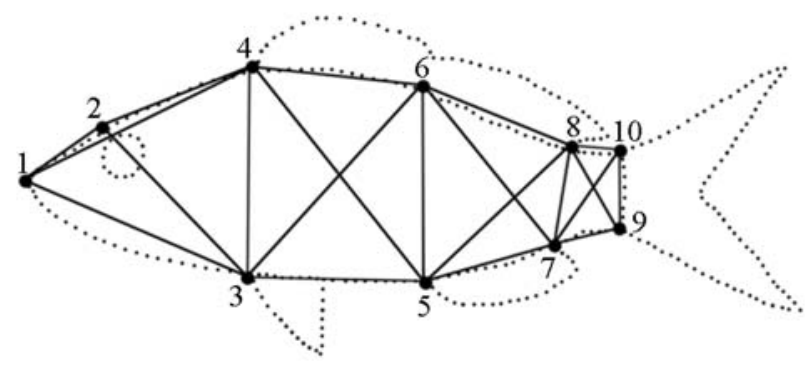

Figure 2 - Outline of Ocyurus chrysurus showing the 10 landmarks and the truss network of measured distances.

Table 1 - Sampling localities and number of specimens used for each analysis.

\begin{tabular}{lccccc}
\hline Locality & Latitude & Longitude & Morphometry & Allozymes & mtDNA \\
\hline CE - Ceará & $3^{\circ} 43^{\prime}$ 02" S & $38^{\circ} 32^{\prime} 34^{\prime \prime} \mathrm{W}$ & 57 & 45 & 17 \\
PE - Pernambuco & $8^{\circ} 45^{\prime} 35^{\prime \prime} \mathrm{S}$ & $35^{\circ} 06^{\prime} 17^{\prime \prime} \mathrm{W}$ & 17 & 5 & 12 \\
BA - Bahia & $13^{\circ} 22^{\prime} 13^{\prime \prime} \mathrm{S}$ & $39^{\circ} 04^{\prime} 23^{\prime \prime} \mathrm{W}$ & 60 & 55 & 12 \\
ES - Espírito Santo & $20^{\circ} 19^{\prime} 10^{\prime \prime} \mathrm{S}$ & $40^{\circ} 20^{\prime} 16^{\prime \prime} \mathrm{W}$ & 58 & 58 & 16 \\
\hline
\end{tabular}


dinates were used for thin-plate spline (TPS) analysis (Bookstein, 1989) which provided shape parameters for subsequent multivariate analyses. Both uniform and nonuniform (= partial warps) components of shape were submitted to a canonical variate analysis (CVA) in order to assess shape variation among populations (Cavalcanti et al., 1999; Zelditch et al., 2004). The PAST program (Hammer et al., 2001) was used for thin-plate spline analysis and partial warps computations. Multivariate statistical analysis (CVA) was performed with SYSTAT ${ }^{\circledR}$ package, v. 10.

\section{Allozyme electrophoresis}

Muscle and liver samples were tested for thirty allozymes and three buffer systems, using $12.5 \%$ starch gel electrophoresis. Based on preliminary results, liver tissue and twelve allozyme systems were chosen for the analyses (Table 2).

Gel slices were stained following standard conditions (Manchenko, 1994; Batista and Solé-Cava, 2005; Lima et al., 2005). Samples that could not be reliably scored for at least half of the allozyme loci were excluded from the analyses. This was the case for most samples from Pernambuco, leading to a severe reduction in allozymes sample size for that locality. Allozyme genotypes were used to estimate allele frequencies, from which heterozygosity levels and inbreeding indices (Global and pairwise $\mathrm{F}_{\mathrm{ST}}$ ) were calculated, using the Genetix 4.01 program (Belkhir et al., 2002). An exploratory factorial correspondence analysis (Excoffier $e t$ al., 1992) was also used, to check for hidden partitions in the allelic hyperspace.

\section{DNA extraction}

Total genomic DNA was extracted from muscle tissues of 77 individuals, using a CTAB extraction protocol (CTAB 2\%, EDTA $20 \mathrm{mM}$, 2-mercaptoethanol $0.2 \% \mathrm{v} / \mathrm{v}$,
$\mathrm{NaCl}$ 1.4 M, Proteinase K 30 micrograms in $500 \mu \mathrm{L}$ of Tris $100 \mathrm{mM}$ ). The extracted DNA was precipitated with ethanol and $3 \mathrm{M}$ sodium acetate, re-suspended in $20 \mu \mathrm{L}$ of ultrapure water, and stored at $-20^{\circ} \mathrm{C}$.

\section{PCR amplification and sequencing}

The PCR reactions of the control-region of mitochondrial DNA (D-loop) were done using the external primers THR (5'AGCTCAGCGCCAGAGCGCCGGTCTTGTA AA3') (Lee et al., 1995) and 12S (5'ATAGTGGGGTAT CTAATCCCAGTT3') (Palumbi et al., 1991). PCR reactions were set up using 1 unit of Taq polymerase, $0.2 \mathrm{mM}$ of each dNTP, $0.5 \mu \mathrm{M}$ of each primer, $1.5 \mathrm{mM}$ of $\mathrm{MgCl}_{2}$, $30 \mu \mathrm{g}$ of BSA (bovine serum albumin) and $1 \mu \mathrm{L}$ of DNA (approx. $50 \mathrm{ng}$ ) as a template, in a final volume of $30 \mu \mathrm{L}$ of PCR buffer (Promega). Thermocycling conditions were: one initial cycle of $5 \mathrm{~min}$ at $94{ }^{\circ} \mathrm{C}$, followed by 35 cycles of 1 min each at $94{ }^{\circ} \mathrm{C}, 48{ }^{\circ} \mathrm{C}$ and $72{ }^{\circ} \mathrm{C}$, and one final extension step of $5 \mathrm{~min}$ at $72{ }^{\circ} \mathrm{C}$. Negative controls (without DNA template) were used in all PCR reactions to check for contamination. PCR products were purified, and both strands were sequenced in an $\mathrm{ABI} 3730 \mathrm{XL}$ automatic sequencer, using the internal PRO (5'CCCAAAGCTAAAA TTCTAA3') (Kocher et al., 1989) and PHE (5'GCTTTAG TTAAGCTACG3') (Hedgecock and Strong, 1994) primers. The different haplotypes obtained were deposited in GenBank under accession numbers DQ666423-DQ666447 and EF624354-EF624386.

\section{Sequence analyses}

Sequences were edited using the SeqmanTM II program (DNAstar Inc.) and aligned using ClustalW (Thompson et al., 1994). For phylogeographic nested clade analysis (NCA), a haplotype network was generated using the TCS 1.21 program (Clement et al., 2000) using the $95 \%$ parsi-

Table 2 - Enzyme systems used in allozyme electrophoresis; buffer systems: TC8 $=0.25 \mathrm{M}$ Tris, $0.06 \mathrm{M}$ citrate, pH 8.0 (Ward and Beardmore, 1977); TC7 = 0.135 M Tris, $0.043 \mathrm{M}$ citrate, $\mathrm{pH} 7.0$ (Shaw and Prasad, 1970); Poulik=0.03 M Tris, $0.005 \mathrm{M}$ citrate, pH 8.5 (gel), $0.06 \mathrm{M} \mathrm{LiOH,} 0.30$ Borate, pH 8.1 (buffer tank) (Poulik, 1957). E.C.: Enzyme Commission numbers.

\begin{tabular}{lccc}
\hline Enzyme & Abbreviation & Buffer & E.C. number \\
\hline Acid phosphatase & ACP & TC8 & 3.1 .3 .2 \\
Alpha-Esterases & $\alpha$ EST & Poulik & 3.1 .1 .1 \\
Glucose 6-Phosphate dehydrogenase & G6PDH & TC8 & 1.1 .1 .49 \\
Glutamate dehydrogenase & GDH & Poulik & 1.4 .1 .2 \\
Glutamic-Oxaloacetic transaminase & GOT & TC7 & 2.6 .1 .1 \\
Lactate dehydrogenase & LDH & TC7 & 1.1 .1 .27 \\
Malic enzyme & ME & TC8 & 1.1 .1 .40 \\
Phosphoglucomutase & PGM & TC7 & 5.4 .2 .2 \\
Phosphogluconate dehydrogenase & PGD & TC8 & 1.1 .1 .44 \\
Phosphoglucose isomerase & PGI & Poulik & 5.3 .1 .9 \\
Superoxide dismutase & SOD & TC8 & 1.15 .1 .1 \\
Xanthine oxidase & XOD & TC8 & 1.1 .3 .22 \\
\hline
\end{tabular}


mony criterion (Templeton, 1998). Clades were nested from haplotypes ( 0 -step) to the highest level, each separated by one substitution step (Templeton et al., 1995; Templeton, 1998), and the statistical significance of each group was assessed, jointly with geographical coordinates for each sample, using the program GeoDis 2.2 (Posada et al., 2000). Selective neutrality of the control region sequences was tested with Tajima's (Tajima, 1996) and Fu's (Fu and Li, 1993) tests. Exact tests of population differentiation (Raymond and Rousset, 1995) were performed with 1,000 dememorisation steps and 10,000 Markov Chain steps. Selective neutrality tests, mismatch distribution analyses (Rogers and Harpending, 1992), Analyses of Molecular Variance (AMOVA; Excoffier et al., 1992) and exact tests of population differentiation were done using the Arlequin 3.0 program (Excoffier et al., 2005). Haplotype and nucleotide diversity indices were estimated using the DNAsp 4 program (Rozas et al., 2003).

\section{Results}

\section{Morphometry}

Morphometric variation among populations was visualized via scatter plot of the scores of the first two canonical variables of the CVA applied to the shape variables of the TPS analysis (Figure 3). The first variable accounted for $76.8 \%$ of the among-population relative to within-population variation and discriminated the southern-most populations (Espírito Santo, Bahia) from the northern ones (Pernambuco, Ceará). A geographical gradient was also observed when considering the intermediate position of the Bahia specimens between Espírito Santo and the northern populations. The second variable accounted for only $26 \%$ of total variation, being related to differences between Ceará and Pernambuco and, to a lesser extent, between Bahia and Espírito Santo. Results of CVA indicated significantly among-populations differences (Wilks lambda $=$ $\left.0.1255 ; \mathrm{F}_{[48,515]}=10.84 ; \mathrm{p}<0.0001\right)$. Percentage of individuals correctly classified to the four original populations ranged from $80 \%$ (Bahia) to $84 \%$ (Ceará and Espírito Santo).

\section{Allozyme electrophoresis}

Eleven loci were scored for all samples. Another four loci were scored for all populations except that of Pernambuco (Table 3). Observed heterozygosities (average Hardy-Weinberg expected heterozygosity, $\mathrm{He}=0.1917$; Table 3) were high (Smith and Fujio, 1982; Ward et al., 1994). Overall, the populations were found to be genetically structured $\left(\mathrm{F}_{\mathrm{ST}}=0.0277 ; 95 \%\right.$ confidence interval (bootstrapping over loci) $=0.00078-0.05648$; standard error (jacknifing across loci) $=0.0195$ reject the null hypothesis of population homogeneity). However, this resulted, mostly, from the large gene frequency differences found in two loci (G6PD-2 and GOT, Table 3) of the population

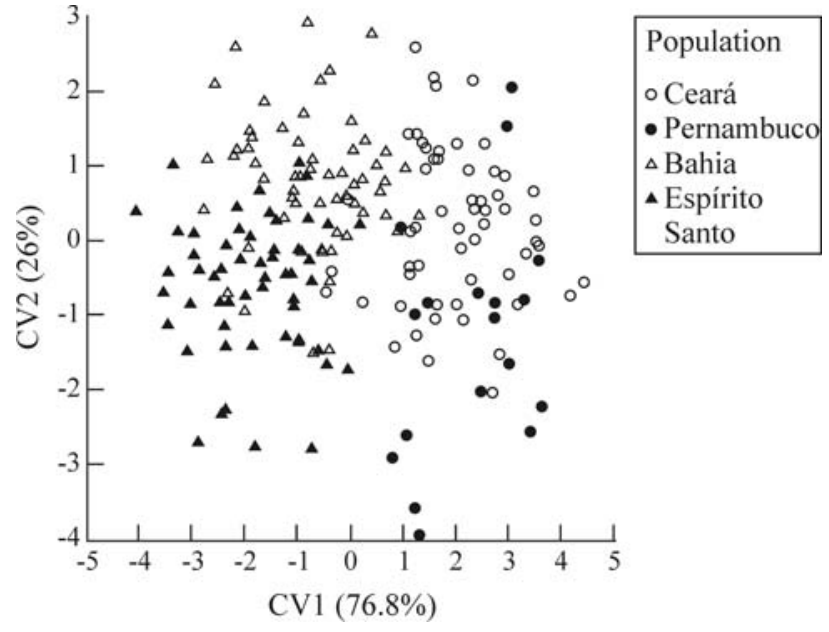

Figure 3 - Scatter plot of individual scores from the first two canonical variates.

from Pernambuco, which was the only one significantly different from the others (Table 4). When the samples from Pernambuco were excluded from the analyses, the $\mathrm{F}_{\mathrm{ST}}$ became non-significant $\left(\mathrm{F}_{\mathrm{ST}}=0.0098 ; \mathrm{p}>0.30\right)$. The factorial correspondence analysis of unclassified samples showed a wide non-significant scatter of the data with only $27.1 \%$ of the total inertia explained by the first two factors (Figure 4). When the gravity centroids of each of the four sampling sites were compared, the two first factors accounted for $84.9 \%$ of the total inertia, showing significant differentiation between Pernambuco and the other sites.

\section{Sequence variation}

From the 663 base pairs of the control region of mitochondrial DNA sequenced, 105 were polymorphic, producing 58 haplotypes in the 77 individuals analysed. Genetic variation over all sampling sites was high (haplotype diversity, $\mathrm{h}=0.9614$; nucleotide diversity, $\pi=0.0185$ ). The highest levels of variation were observed in Belize $(h=1.000 ; \pi=0.02378)$. The null hypothesis of selective neutrality was not rejected for the studied sequences (Tajima's D test; $p>0.05$; Fu's Fs test; $p>0.05$ ) from most sampling sites. An exception was the Belize population, where D was not significantly different from zero, but Fu's Fs was significantly negative $(F s=-8.88 ; p<0.001)$. A negative $F s$ results from an excess of rare alleles (as can be observed in the haplotype network in Figure 5), and it is usually interpreted as an indication of population expansion (Harpending, 1994). Hence, a mismatch distribution analysis (Rogers and Harpending, 1992) was performed on that population (Figure 6), and the observed distribution did not deviate significantly from the null hypothesis of population expansion ( $\mathrm{SSD}=0.004 ; \mathrm{p}>0.95)$. The Harpending's Raggedness index was low $(\mathrm{r}=0.010)$, indicating a smooth distribution, also consistent with the hypothesis of population expansion (Harpending, 1994). 
Table 3 - Allele frequencies for the 14 loci analysed. For simplicity, the slowest migrating allele for each locus is not shown: its frequency can be calculated as one minus the frequency of the other alleles at that locus in the population. $\mathrm{N}=$ number of individuals analysed; $\mathrm{He}=$ mean Hardy-Weinberg expected heterozygosity; Ho = mean observed heterozygosity (values shown as average \pm standard error)

\begin{tabular}{|c|c|c|c|c|}
\hline Locus/allele & Ceará $(\mathrm{N}=45)$ & Pernambuco $(\mathrm{N}=5)$ & Bahia $(\mathrm{N}=55)$ & Espírito Santo $(\mathrm{N}=58)$ \\
\hline$A C P / \mathrm{A}$ & 0.97 & 1 & 1 & 1 \\
\hline$\alpha-E S T / A$ & 0.28 & 0.10 & 0.15 & 0.13 \\
\hline$G D H / \mathrm{A}$ & 0.37 & 0.30 & 0.41 & 0.41 \\
\hline$G 6 P D-1 / \mathrm{A}$ & 0.53 & 0.30 & 0.44 & 0.41 \\
\hline$G 6 P D-2 / \mathrm{A}$ & 0.58 & 1 & 0.31 & 0.41 \\
\hline$G O T / \mathrm{A}$ & 0.23 & 0 & 0.39 & 0.41 \\
\hline.$/ \mathrm{B}$ & 0.74 & 1 & 0.61 & 0.59 \\
\hline$L D H-1 / \mathrm{A}$ & 0 & 0 & 0.01 & 0.05 \\
\hline$L D H-2 / \mathrm{A}$ & 1 & 1 & 1 & 1 \\
\hline$M E / A$ & 1 & 1 & 1 & 1 \\
\hline$P G D-1 / A$ & 1 & 1 & 1 & 1 \\
\hline$P G I-1 / \mathrm{A}$ & 0.59 & ND & 0.54 & 0.64 \\
\hline$P G I-2 / \mathrm{A}$ & 0.50 & ND & 0.51 & 0.59 \\
\hline$P G M / \mathrm{A}$ & 0.50 & ND & 0.63 & 0.42 \\
\hline.$/ \mathrm{B}$ & 0.46 & ND & 0.37 & 0.58 \\
\hline$S O D / \mathrm{A}$ & 0.97 & ND & 1 & 0.98 \\
\hline$X O D / \mathrm{A}$ & 1 & 1 & 1 & 1 \\
\hline $\mathrm{He}$ & $0.234 \pm 0.240$ & $0.076 \pm 0.533$ & $0.223 \pm 0.236$ & $0.234 \pm 0.232$ \\
\hline Ho & $0.140 \pm 0.180$ & $0.094 \pm 0.182$ & $0.192 \pm 0.244$ & $0.185 \pm 0.219$ \\
\hline
\end{tabular}

Table 4 - Pairwise $\mathrm{F}_{\mathrm{ST}}$ values among the four Brazilian populations for allozyme data. Probability values $\left(\mathrm{H}_{\mathrm{o}}: \mathrm{F}_{\mathrm{ST}}=0\right)$ were calculated by 1000 bootstrap permutations. NS = not significant; $*=\mathrm{p}<0.05 ; * *=\mathrm{p}<0.01$

\begin{tabular}{lcc}
\hline Population 1 & Population 2 & Allozyme $\mathrm{F}_{\mathrm{ST}}$ \\
\hline Espírito Santo & Ceará & $0.0113^{\mathrm{NS}}$ \\
Espírito Santo & Pernambuco & $0.1726^{*}$ \\
Espírito Santo & Bahia & $0.0005^{\mathrm{NS}}$ \\
Ceará & Pernambuco & $0.1010^{\mathrm{NS}}$ \\
Ceará & Bahia & $0.0202^{\mathrm{NS}}$ \\
Pernambuco & Bahia & $0.2256^{* *}$ \\
\hline
\end{tabular}

Levels of population differentiation, as indicated by pairwise $\mathrm{F}_{\mathrm{ST}}$ values, were significant only between the population from Belize and the others (Tables 4 and 5). No differentiation was observed among populations from Brazil with the exact tests of population differentiation (Markov chain test; exact $P$ value $=0.72255 \pm 0.02941)$. This was confirmed by AMOVA, where none of the $\Phi_{\mathrm{ST}}$ values among Brazilian populations was significant, and less than $7 \%$ of the total variance was explained by differences between geographical locations (Table 6). The nested clade analysis did not reveal significant $(\mathrm{p}>0.05$ after Bonferroni correction) groupings at any hierarchical level. Seven haplotypes, five of which from Belize, were excluded from the nested-clade analysis because they did not meet the $95 \%$ confidence level on the TCS haplotype network. This

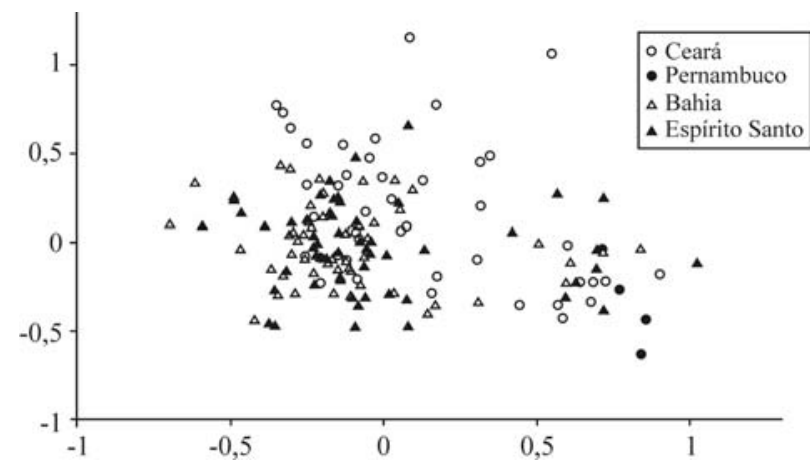

Figure 4 - Correspondence factorial analysis of allozyme data.

was caused by the very large divergence of those sequences in relation to the others, as can be seen in the neighbor-joining tree of all haplotypes (Figure 7).

\section{Discussion}

The analysis of both nuclear and mitochondrial genetic data of populations of yellowtail snappers, Ocyurus chrysurus, did not reveal genetic differences that could justify rejecting the null hypothesis of panmixia along the $2380 \mathrm{~km}$ of Brazilian coast, but significant differences were observed between Brazilian and Caribbean populations. In contrast, we observed significant differences in the mor- 
phology of the Brazilian samples $\left(\mathrm{F}_{[48,515]}=10.84\right.$; $\mathrm{p}<0.0001)$.

Some heterogeneity was observed in allozyme frequencies among Brazilian populations $\left(\mathrm{F}_{\mathrm{ST}}=0.0277\right.$; $\mathrm{p}<0.05$ ). This heterogeneity was caused by the large differences observed between Pernambuco and other Brazil-

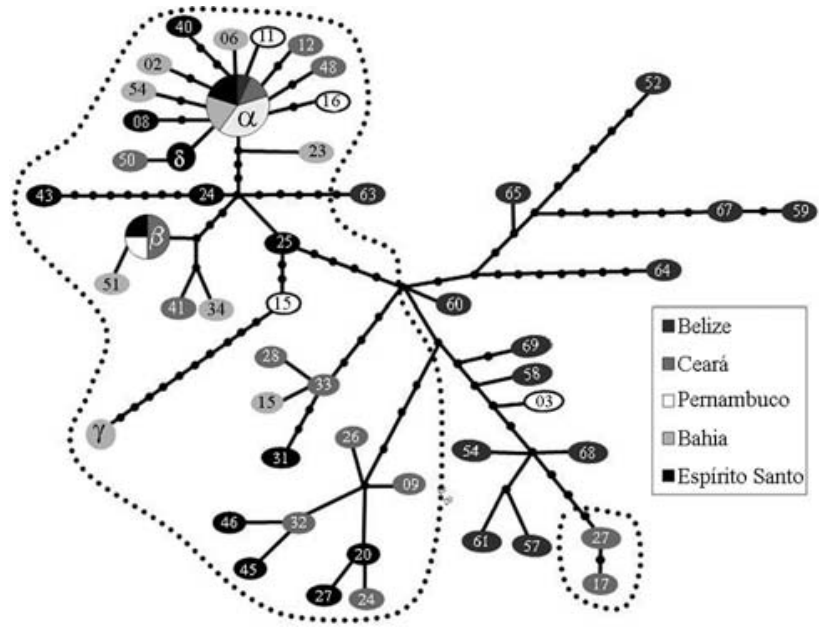

Figure 5 - mtDNA control-region haplotype network. Different shades of grey are used to indicate sample locations. Hypothetical non-sampled haplotypes are indicated by dots. Lines connecting haplotypes correspond to single nucleotide changes. Dotted line surrounds haplotype clusters from the southwestern Atlantic. Haplotype $\alpha$ : samples CE22, CE06, PE01, PE06, PE10, PE13, PE14, PE17, BA10, BA11, BA47, ES04, ES07, ES41, BE62; Haplotype $\beta$ : CE05, CE53, PE4, ES42; Haplotype $\gamma$ : BA43, BA46; Haplotype $\delta$ : ES28, ES52.

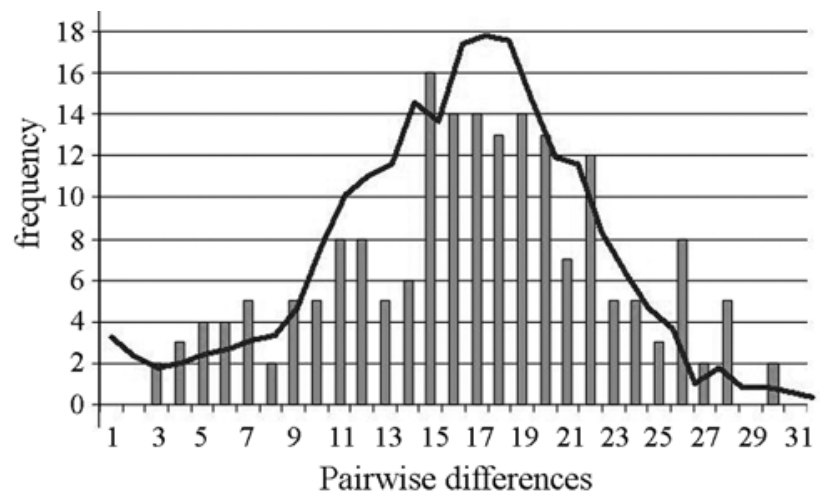

Figure 6 - Mismatch distribution analysis for the Belize population. The line shows the expected distribution under the null hypothesis of population expansion. ian populations (Table 4, Figure 4). However, since only 5 individuals were analysed from that population, it is likely that the differences encountered simply result from sampling error. Indeed, when we excluded Pernambuco from the analysis, the mean $\mathrm{F}_{\mathrm{ST}}$ values became non-significant $\left(F_{S T}=0.0098 ; p>0.30\right)$. Therefore, we cautiously conclude that there is no support from the allozyme data to reject the null hypothesis of panmixia in this species along the studied area on the Brazilian coast.

The control region of $O$. chysurus is extremely variable (haplotype diversity $=0.9614$ ). However, this variability is much higher within than between sampling locations in Brazil (Tables 5 and 6), and both the haplotype network generated by nested-clade analysis (Figure 5) and the complete haplotype tree (Figure 7) show that the haplotypes from the Brazilian samples are distributed haphazardly along the coast. The Caribbean samples, on the other hand, differ significantly from the southwestern Atlantic ones $\left(\mathrm{F}_{\mathrm{ST}}=0.17, \mathrm{p}<0.05\right.$; Table 5$)$. This can also be seen in the haplotype network and the haplotype tree (Figures 5 and 7 ), where most samples from Belize cluster outside of the southwestern Atlantic ones. The haplotype network has a

Table 6 - Results of the analysis of molecular variance (AMOVA) from mtDNA sequence data of the Brazilian populations. O.B.P. $=$ Other Brazilian Populations. ${ }^{*} \mathrm{p}<0.05$

\begin{tabular}{lcc}
\hline Groups & $\begin{array}{c}\text { Among } \\
\text { groups }\end{array}$ & $\begin{array}{c}\text { Within } \\
\text { populations }\end{array}$ \\
\hline Ceará X O.B.P. & -3.95 & 100.00 \\
Pernambuco X O.B.P. & 1.51 & 97.66 \\
Bahia X O.B.P. & -2.01 & 99.39 \\
Espírito Santo X O.B.P. & 4.25 & 96.31 \\
Ceará and Pernambuco X O.B.P. & -1.50 & 98.90 \\
Ceará and Bahia X O.B.P. & -2.30 & 99.16 \\
Ceará and Espírito Santo X O.B.P. & 3.74 & 97.18 \\
Ceará X Pernambuco X O.B.P. & -3.33 & 98.95 \\
Pernambuco X Bahia X O.B.P. & 2.59 & 97.98 \\
Pernambuco X Espírito Santo X O.B.P. & 3.43 & 97.84 \\
Bahia X Ceará X O.B.P. & -7.19 & 99.58 \\
Bahia X Espírito Santo X O.B.P. & 0.91 & 98.25 \\
Ceará X Espírito Santo X O.B.P. & 3.43 & 97.84 \\
Belize X Brazilian populations & 17.57 & $81.63 *$ \\
\hline
\end{tabular}

Table 5 - Pairwise mtDNA $\mathrm{F}_{\mathrm{ST}}$ values between $O$. chrysurus populations (below the diagonal). The significance of each value $\left(\mathrm{H}_{\mathrm{o}}\right.$ : $\left.\mathrm{F}_{\mathrm{ST}}=0\right)$ is shown above the diagonal. $* \mathrm{p}<0,05$.

\begin{tabular}{lccccc}
\hline & Belize & Ceará & Pernambuco & Bahia & Espírito Santo \\
\hline Belize & & $0.000+-0.00^{*}$ & $0.000+-0.00^{*}$ & $0.000+-0.00^{*}$ & $0.000+-0.00^{*}$ \\
Ceará & 0.07763 & & $0.054+-0.03$ & $0.117+-0.03$ & $0.468+-0.04$ \\
Pernambuco & 0.21298 & 0.07341 & & $0.657+-0.07$ & $0.216+-0.02$ \\
Bahia & 0.17277 & 0.04022 & -0.02348 & & $0.315+-0.03$ \\
Espírito Santo & 0.17159 & -0.00254 & 0.01821 & 0.01320 & \\
\hline
\end{tabular}




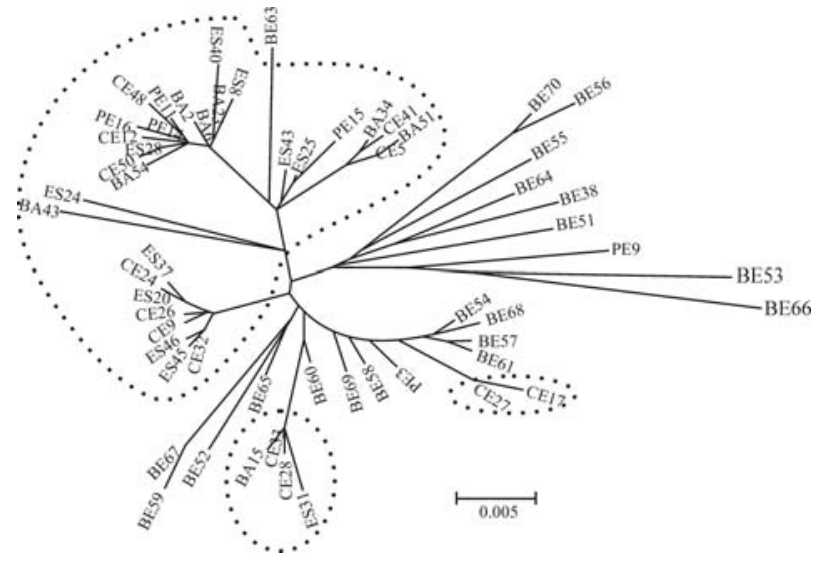

Figure 7 - mtDNA control-region haplotype neighbor-joining tree (Kimura 2-parameter distance). Dotted line surrounds haplotype clusters from the southwestern Atlantic.

signal of recent population expansion (star-shaped topology around haplotype $\alpha$ in Figure 5), but that grouping was not significant in the nested-clade analysis, and none of the Brazilian samples presented deviations from neutrality in both Fu's and Tajima's tests. On the other hand, the sequences of the population from Belize diverged from neutral expectation (Fu's Fs $=-8.88 ; \mathrm{p}<0.001$ ), and the mismatch distribution analysis (Figure 6) had a mode of 15 nucleotide differences, which is a clear signal of an old population expansion. The analysis of mtDNA thus indicates that the population from the Caribbean is old and currently stable. It shows also that the Caribbean population is different from the Brazilian one which is homogeneous along its distribution.

The results of the morphometric geometric analyses show what seems to be a north-south gradient of body shape, ranging from fusiform individuals, with a long caudal fin in specimens from the north to more rounded individuals, with shorter caudal fin in the south. Gradients in morphometric characters are often associated to phenotypic plasticity (O'Reilly and Horn, 2004). The morphometric differences observed are not incompatible with the existence of discrete fish stocks, since patterns of reef fish community change along the Brazilian coast often show a north-south differentiation (Floeter et al., 2001), but this result contrasts with the homogeneity observed with both nuclear and mitochondrial data. It has been argued that morphometric analyses can sometimes detect subtle differences in stock structure which are undetectable by genetic data, particularly when stock structure is the result of very recent population subdivision (Cadrin, 2000). However, the differences in morphometric data on a background of genetic homogeneity could also indicate phenotypic plasticity. This phenomenon may occur as response to gradients in environmental cues (Via et al., 1995). Such environmental gradient is likely to occur along a geographic range of more than $15^{\circ}$ of latitude and ca. $2,400 \mathrm{~km}$ of coastline as the one inhabited by the studied Brazilian populations of Ocyurus chrysurus. Differences in oceanographic conditions, mainly sea-water temperature, were reported to this area (Castro and Miranda, 1998) being regarded as an important factor in the genetic differentiation of Macrodon ancylodon populations along the Brazilian coast (Santos et al., 2003). Cases where morphometric and genetic data indicate different scenarios of population structuring are not uncommon (Salini et al., 2004; Levi et al., 2004). In the case of Ocyurus chrysurus, the fact that the morphological variation observed formed a gradient is a clear indication that it has likely resulted from phenotypic plasticity. We thus conclude that the genetic data do not allow the rejection of the null hypothesis of panmixia for Brazilian yellowtail snapper populations which could be treated as a single genetic stock, with a latitudinal gradient on their morphology. On the other hand, there is a severe restriction to gene flow between $O$. chrysurus populations from the Caribbean and from the southwestern Atlantic.

\section{Acknowledgments}

The authors thank Drs. Carlos Arthur Sobreira Rocha, Rosangela Lessa, Agnaldo Silva Martins, George Olavo Mattos e Silva, Paulo Roberto Duarte Lopes and many others from the REVIZEE program for invaluable support during the first stages of this work. We thank Dr. Luiz Rocha for samples collection in Belize. Cristiano Lazoski revised an earlier version of this manuscript. This work is part of the thesis in Genetics of Anderson Vasconcellos. Financial support for this work was provided by the REVIZEE program, by CNPq and FAPERJ.

\section{References}

Allen GR (1985) Snappers of the world. An annotated and illustrated catalogue of lutjanid species known to date. FAO Fish Synop 125:1-208.

Allman JA, Barbieri LR and Bartels CT (2005) Regional and fishery-specific patterns of age and growth of yellowtail snapper, Ocyurus chrysurus. Gulf Mex Sci 2005:211-223.

Batista RP and Solé-Cava A (2005) Baixa diferenciação genética entre populações do peixe-batata (Lopholatilus villarii Miranda-Ribeiro, 1915) ao norte e sul do banco dos Abrolhos, Brasil. In: PAS Costa, AS Martins and G Olavo (ed.) Pesca e Potenciais de Exploração de Recursos Vivos na Região Central da Zona Econômica Exclusiva Brasileira. Editora da UFRJ, Rio de Janeiro, pp 241-247.

Belkhir K, Borsa P, Chikhi L, Raufaste N and Bonhomme F (2002) GENETIX 4.04, logiciel sous Windows TM pour la génétique des populations. Montpellier (France). Laboratoire Génome, Populations, Interactions, CNRS UMR 5000, Université de Montpellier II.

Blaber SJM, Dichmont CM, Buckworth RC, Badrudin, Sumiono B, Nurhakim S, Iskandar B, Fegan B, Ramm DC and Salini JP (2005) Shared stocks of snappers (Lutjanidae) in Australia and Indonesia: Integrating biology, population dynamics and socio-economics to examine management scenarios. Rev Fish Biol Fish 15:111-127. 
Booke HE (1981) The conundrum of the stock concept - Are nature and nurture definable in fisheries science? Can J Fish Aquat Sci 38:1479-1480.

Bookstein FL (1989) Principal warps: Thin-plate splines and the decomposition of deformations. IEEE Trans Pat Anal Mach Intel 11:567-585.

Caddy JF and Seijo JC (2005) This is more difficult than we thought! The responsibility of scientists, managers and stakeholders to mitigate the unsustainability of marine fisheries. Phil Trans Royal Soc B 360:59-75.

Cadrin SX (2000) Advances in morphometric identification of fishery stocks. Rev Fish Biol and Fish 10:91-112.

Carmen MA and Ablan A (2006) Genetics and the study of fisheries connectivity in Asian developing countries. Fish Res 78:158-168.

Carvalho GR and Hauser L (1995) Molecular genetics and the stock concept in fisheries. In: Carvalho GR and Pitcher TJ (eds) Molecular Genetics in Fisheries. Chapman \& Hall, London, pp 55-79.

Castro BM and Miranda LBd (1998) Physical oceanography of the western Atlantic Continental Shelf located between $4^{\circ} \mathrm{N}$ and $34^{\circ} \mathrm{S}$ coastal segment $(4, \mathrm{~W})$. In: Robinson $\mathrm{AR}$ and Brink KH (eds) The Sea VII. John Wiley and Sons Inc, London, pp 209-251.

Cavalcanti MJ, Monteiro LR and Lopes PRD (1999) Landmarkbased morphometric analysis in selected species of serranid fishes (Perciformes, Teleostei). Zool Stud 38:287-294.

Claro R (1983) Ecologia y ciclo de vida de la rabirrubia, $O$. chrysurus (Bloch), en la plataforma cubana. II. Edad y crecimiento, estructura de poblaciones y pesquerias. Rep Invest Inst Oceanol Acad Cien Cuba 19:1-33.

Clement M, Posada M and Crandall KA (2000) TCS: A computer program to estimate gene genealogies. Mol Ecol 9:16571660.

Costa PAS, Braga AD and da Rocha LOF (2003) Reef fisheries in Porto Seguro, Eastern Brazilian Coast. Fish Res 60:577-583.

Excoffier L, Laval G and Schneider S (2005) Arlequin ver. 3.0: An integrated software package for population genetics data analysis. Evol Bioinf Online 1:47-50.

Excoffier L, Smouse PE and Quattro JM (1992) Analysis of molecular variance inferred from metric distances among DNA haplotypes-application to human mitochondrial-DNA restriction data. Genetics 131:479-491.

Fallows JA (1984) The behavioural ecology of feeding in the yellowtail snapper, Ocyurus chrysurus (Family Lutjanidae). $\mathrm{PhD}$ Thesis, University of Newcastle Upon Tyne, Newcastle.

FAO (2002) El Estado Mundial de la Pesca y la Acuicultura. Food and Agriculture Organization of the United Nations, Rome, $150 \mathrm{pp}$.

Floeter SR, Guimarães RZP, Rocha LA, Ferreira CEL, Rangel CA and Gasparini JL (2001) Geographic variation in reef-fish assemblages along the Brazilian coast. Global Ecol Biogeogr 10:423-431.

Fu YX and Li WH (1993) Statistical tests of neutrality of mutations. Genetics 133:693-709.

Garcia SM and Grainger RJR (2005) Gloom and doom? The future of marine capture fisheries. Phil Trans Royal Soc B 360:21-46.

Grimes CB (1987) Reproductive biology of the Lutjanidae: A review. In: Polovina JJ and Ralston S (eds) Tropical Snappers and Groupers: Biology and Fisheries Management. Westview Press, Boulder, pp 239-294.

Hammer O, Harper DAT and Ryan PD (2001) PAST: Paleontological Statistics Software Package for Education and Data Analysis. Palaeont Elect 4(1).

Harpending HC (1994) Signature of ancient population growth in a low-resolution mitochondrial DNA mismatch distribution. Hum Biol 66:591-600.

Hedgecock D and Strong DR (1994) Conservation biology of endangered Pacific salmonids: Introductory remarks. Cons Biol 8:863-894

Ihssen PE, Booke HE, Casselman JM, McGlade JM, Payne NR and Utter FM (1981) Stock identification: Materials and methods. Can J Fish Aquat Sci 38:1838-1855.

Kocher TD, Thomas WK, Meyer A, Edwards SV, Paabo S, Villablanca FX and Wilson AC (1989) Dynamics of mitochondrial DNA evolution in animals: Amplification and sequencing with conserved primers. Proc Nat Acad Sci USA 86:6196-6200.

Lee W-J, Conroy J, Howell WH and Kocher TD (1995) Structure and evolution of teleost mitochondrial control regions. J Mol Evol 41:54-66.

Levi D, Patti B, Rizzo P, Lo Brutto S, Parrinello N and Arculeo M (2004) Genetic and morphometric variations of Mediterranean hake, Merluccius merluccius, in the Strait of Sicily (central Mediterranean): Implications for stock assessment of shared resources. Ital J Zool 71:165-170.

Lima D, Freitas JE, Araujo ME and Solé-Cava AM (2005) Genetic detection of cryptic species in the frillfin goby Bathygobius soporator. J Exp Mar Biol Ecol 320:211-223.

Manchenko GP (1994) Handbook of Detection of Enzymes on Electrophoretic Gels. CRC Press Inc, Ann Arbor, 341 pp.

Menezes NA and Figueiredo JL (1980) Manual de Peixes Marinhos do Sudeste do Brasil. IV Teleostei (3). Museu de Zoologia, São Paulo, 96 pp.

O'Reilly K and Horn MH (2004) Phenotypic variation among populations of Atherinops affinis (Atherinopsidae) with insights from a geometric morphometric analysis. J Fish Biol 64:1117-1135.

Ormerod SJ (2003) Current issues with fish and fisheries: Editor's overview and introduction. J Appl Ecol 40:204-213.

Ovenden JR (1990) Mitochondrial DNA and marine stock assessment: A review. Austr J Mar Freshwat Res 41:835-853.

Paiva MP and Andrade-Tubino MF (1998) Distribuição e abundância de peixes bentônicos explotados pelos linheiros ao largo do sudeste do Brasil (1986-1995). Rev Bras Biol 58:619-632.

Palumbi SR, Martin A, Romano S, McMillan WO, Stice L and Grabowski G (1991) The Simple Fools Guide to PCR, Version 2.0. Univ. Hawaii, Honolulu, 47 pp.

Parrish JD (1987). The trophic biology of snappers and groupers. In: Polovina JJ and Ralston S (eds) Tropical Snappers and Groupers: Biology and Fisheries Management. Westview Press, Boulder, pp 405-463.

Pauly D, Watson R and Alder J (2005) Global trends in world fisheries: Impacts on marine ecosystems and food security. Phil Trans R Soc B 360:5-12.

Posada D, Crandall KA and Templeton AR (2000) GeoDis: A program for the cladistic nested analysis of the geographical distribution of genetic haplotypes. Mol Ecol 9:487-488. 
Poulik MD (1957) Starch gel electrophoresis in a discontinuous system of buffers. Nature 180:1477-1479.

Raymond M and Rousset F (1995) An exact test for population differentiation. Evolution 49:1280-1283.

Resende SM, Ferreira BP and Fredou T (2003) A pesca de Lutjanídeos no nordeste do Brasil: Histórico das pescarias, características das espécies e relevância para o manejo. Bol Tecn Cient CEPENE 11:257-270.

Riley CM, Holt GJ and Arnold CR (1995) Growth and morphology of larval and juvenile captive bred Yellowtail Snapper, Ocyurus chrysurus. Fish Bull 93:179-185.

Rogers AR and Harpending H (1992) Population growth makes waves in the distribution of pairwise genetic differences. Mol Biol Evol 9:552-569.

Rohlf FJ and Slice DE (1990) Extensions of the Procrustes method for the optimal superimposition of landmarks. Syst Zool 39:40-59.

Rozas J, Sánchez-DelBairro JC, Messeguer X and Rozaz R (2003) DNAsp: DNA polymorphism analyses by the coalescent and other methods. Bioinformatics 19:2496-2497.

Ryman N (1991) Conservation genetics considerations in fishery management. J Fish Biol 39:211.

Ryman N and Utter F (1987) Population genetics and fishery management. Washington University Press, London, 420 pp.

Salini JP, Milton DA, Rahman MJ and Hussain MG (2004) Allozyme and morphological variation throughout the geographic range of the tropical shad, hilsa Tenualosa ilisha. Fish Res 66:53-69.

Santos S, Schneider H and Sampaio MI (2003) Genetic differentiation of Macrodon ancylodon (Sciaenidae, Perciformes) populations in Atlantic coastal waters of South America as revealed by mtDNA analysis. Genet Mol Biol 26:151-161.

Shaw PR and Prasad R (1970) Starch gel eletroforesis of enzymes - A compilation of recipes. Biochem Genet 4:297-320.

Slice DE (1998) Morpheus et al:: Software for morphometric research. Department of Ecology and Evolution, State University of New York, New York.

Smith PJ and Fujio Y (1982) Genetic variation in marine teleosts: High variability in habitat specialists and low variability in habitat generalists. Mar Biol 69:7-20.
Smith PJ, Jamieson A and Birley AJ (1990) Electrophoretic studies and stock concept in marine teleosts. J Cons Int Explor Mer 47:231-245.

Strauss RE and Bookstein FL (1982) The truss: Body form reconstruction in morphometrics. Syst Zool 31:113-135.

Tajima F (1996) The amount of DNA polymorphism maintained in a finite population when the neutral mutation rate varies among sites. Genetics 143:1457-1465.

Templeton AR (1998) Nested clade analyses of phylogeographic data: Testing hypotheses about gene flow and population history. Mol Ecol 7:381-397.

Templeton AR, Routman E and Phillips CA (1995) Separating population structure from population history: A cladistic analyses of the geographical distribution of mitochondrial DNA haplotypes in the tiger salamander, Ambystona tigrinum. Genetics 140:767-782.

Thompson JD, Higgins DG and Gibson TJ (1994) CLUSTAL W: Improving the sensitivity of progressive multiple sequence alignment through sequence weighting, position-specific gap penalties and weight matrix choice. Nucleic Acids Res 22:4673-4680.

Thompson R and Munro JL (1983) The biology, ecology and bionomics of Caribbean reef fishes: Lutjanidae (snappers). In: Munro JL (ed) Caribbean Coral Reef Fishery Resources ICLARM Stud Rev 7. Manila, Philippines, pp 94-109.

Vasconcellos M and Gasalla MA (2001) Fisheries catches and the carrying capacity of marine ecosystems in southern Brazil. Fish Res 50:279-295.

Via S, Gomulkiewicz R, de Jong G, Scheiner SM, Schlichting CD and Van Tienderen PH (1995) Adaptive phenotypic plasticity: Consensus and controversy. Trends Ecol Evol 10:212217.

Ward RD and Beardmore JA (1977) Protein variation in the plaice (Pleuronectes platessa). Genet Res 30:45-62.

Ward RD, Woodwark M and Skibinski DOF (1994) A comparison of genetic diversity levels in marine, fresh-water, and anadromous fishes. J Fish Biol 44:213-232.

Watson M, Munro JL and Gell FR (2002) Settlement, movement and early juvenile mortality of the yellowtail snapper Ocyurus chrysurus. Mar Ecol Prog Ser 237:247-256.

Zelditch ML, Swiderski DL, Sheets HD and Fink WL (2004) Geometric morphometrics for biologists: A primer. Elsevier Academic Press, San Diego, 443 pp.

Associate Editor: Maria Iracilda Sampaio

License information: This is an open-access article distributed under the terms of the Creative Commons Attribution License, which permits unrestricted use, distribution, and reproduction in any medium, provided the original work is properly cited. 